\title{
KIF4A wt Allele
}

National Cancer Institute

\section{Source}

National Cancer Institute. KIF4A wt Allele. NCI Thesaurus. Code C63506.

Human KIF4A wild-type allele is located in the vicinity of Xq13.1 and is approximately 131 $\mathrm{kb}$ in length. This allele, which encodes chromosome-associated kinesin KIF4A protein, is involved in the regulation of microtubule directionality and subsequent cellular movement. 